\title{
Proposal of a New Genus, Gordona, for Slightly Acid-fast Organisms Occurring in Sputa of Patients With Pulmonary Disease and in Soil
}

\author{
By M. TSUKA MURA \\ The National Sanatorium, Chubu Chest Hospital, \\ Obu, Aichi-Ken 474, Japan
}

(Accepted for publication I7 June I97I)

\begin{abstract}
SUMMAR Y
A new genus Gordona has been proposed for slightly acid-fast organisms which occur in sputa of patients with pulmonary disease and in soil. This genus is considered to contain 'Mycobacterium' rhodochrous-like organisms. The genera Mycobacterium and Gordona are characterized by absence of mycelium and slight or strong acid-fastness. The genus Gordona shows characters intermediate between the genera Mycobacterium and Nocardia. It is distinguished from rapidgrowing mycobacteria by its slight acid-fastness (weaker than Mycobacterium), absence of arylsulphatase activity at 2 weeks, ability to utilize sucrose as a sole carbon source and inability to utilize trimethylene diamine as a simultaneous nitrogen and carbon source. The genus is distinguished from nocardias by the absence of mycelium, ability to form acid from mannose, positive nitrate reduction and ability to utilize sucrose as a sole carbon source. It can be isolated from sputa of patients with lung cavities or bronchiectasis and from soil by prior treatment with alkali. The organisms are Gram-positive or variable; slightly acid-fast, that is, stained light pink or light violet by the Ziehl-Neelsen method; mycelium not formed; spores not formed; non-motile; aerobic; catalase-positive; oxidase-negative; acid formed from glucose by oxidation; growth occurs at $28^{\circ}$ and $37^{\circ}$ but not at $45^{\circ}$; growth at 2 to 3 days forming rough, reddish or pinkish colonies in air; occur as short rods; non-pathogenic for mice, rabbits, guinea pigs and chickens. Type species is Gordona bronchialis.
\end{abstract}

\section{INTRODUCTION}

During the course of studies on 'atypical' mycobacteria from clinical specimens, a number of organisms forming rough pinkish or reddish colonies on egg media as isolated from sputa of patients with pulmonary disease. Similar organisms were isolated from soils. These organisms showed intermediate characters between the genus Mycobacterium and the genus Nocardia but were distinguished from these genera by several common characters. The organisms most resembled 'Mycobacterium' rhodochrous, an organism whose taxonomy is not yet clarified (Gordon \& Mihm, I957, I959; Gordon, 1966). A new genus Gordona is proposed for these organisms.

\section{METHODS}

Isolation. Sputum specimens from patients with pulmonary disease (cavitary pulmonary tuberculosis and/or bronchiectasis) were added to an equal volume of $4 \%(\mathrm{w} / \mathrm{v}) \mathrm{NaOH}$ solution and liquefied by incubation at $37^{\circ}$ for $30 \mathrm{~min}$. or by shaking vigorously at room temperature for 15 to $30 \mathrm{~min}$. The sputum specimen was then inoculated on Ogawa egg 
medium (Löwenstein-Jensen medium may be used) with a pipette or a spiral loop, and incubated at $37^{\circ}$ for 4 to 8 weeks. The organisms growing on the medium were subcultured on Ogawa egg medium slopes containing $0.5 \mathrm{mg}$. sodium salicylate $/ \mathrm{ml}$. which excluded the growth of tubercle bacilli. After incubation at $37^{\circ}$ for 3 weeks, strains growing on the salicylate medium were stained by the Ziehl-Neelsen method, the majority belonged to the 'atypical' mycobacteria group (mycobacteria other than tubercle bacilli) (Tsukamura, I 962). Some organisms showed only slight acid-fastness and occurred as short rods. These organisms formed rough reddish or pinkish colonies on egg medium when incubated in tubes with cotton-wool plugs.

Similar organisms were isolated from soils. Five g. of a soil sample were suspended in $25 \mathrm{ml}$. of distilled water and shaken vigorously in a $300 \mathrm{ml}$. Erlenmeyer flask at room temperature in a reciprocating shaker (stroke: $10 \mathrm{~cm}$; 60 cycles $/ \mathrm{min}$.) for $30 \mathrm{~min}$. The suspension was allowed to stand for $10 \mathrm{~min}$. and $15 \mathrm{ml}$. of the resulting supernatant was added to an equal volume of $8 \%(\mathrm{w} / \mathrm{v}) \mathrm{NaOH}$ solution, shaken for $10 \mathrm{~min}$. and then centrifuged at $500 \mathrm{~g}$ for $\mathrm{I} 5 \mathrm{~min}$. The residue was suspended in $\mathrm{I} 0 \mathrm{ml}$. of $\mathrm{I} \% \mathrm{o} / \mathrm{w} / \mathrm{v}) \mathrm{NaH}_{2} \mathrm{PO}_{4}$ solution and inoculated on Ogawa egg medium slopes with a spiral loop delivering $0.02 \mathrm{ml}$. The medium was incubated at $37^{\circ}$ for 2 to 4 weeks and organisms growing as rough reddish colonies were selected and purified by single colony-isolation techniques.

Strains. Six strain were received as 'Mycobacterium' rhodochrous. Among these, one strain (ATCC 13808) was received directly from the American Type Culture Collection, Rockville, Maryland, U.S.A., and five strains from Dr M. Goodfellow, Department of Microbiology, Medical School, University of Newcastle upon Tyne. The history of the strains are as follows: (I) tsu ' $M$.' rhodochrous (without information of history); (2) N 30 'M.' rhodochrous; R. E. Gordon, A I2974; ATCC I2974; W. H. Burkholder, CF I7; P. E. Tilford; (3) N 3 I ' $M$.' rhodochrous; R. E. Gordon, W 2 I; S. A. Waksman; R. S. Breed; (4) N 55 'M.' rhodochrous; R. E. Gordon, 817; L. S. McClung, B I6I A; (5) N 56 'M.' rhodochrous; R. E. Gordon, I256; A. I. Laskin, 2914; from soil. A strain of Mycococcus luteus, вKм B-963, was received from Dr M. Fateeva, All Union Collection of Micro-organisms, Moscow, U.S.S.R.

Tests. A total of roo characters was recorded (see Table 4) by means of methods described previously (Tsukamura, I966, 1967). Four additional tests, found to be useful for differentiation of mycobacteria (Tsukamura, 1969), were included in this study. They were not included in the tests used to calculate S-values, as they had not been used in the previous studies. These tests were: ( I ) growth on Sauton agar containing $0 \cdot \mathrm{I} \%$ (w/v) $\mathrm{NaNO}_{2}$; (2) growth on Sauton agar containing $0.2 \%(\mathrm{w} / \mathrm{v}) \mathrm{NaNO}_{2}$; (3) growth on Sauton agar containing $\mathrm{I} \%(\mathrm{w} / \mathrm{v})$ Tween 80 ; (4) growth on the Ogawa egg medium to which $5 \mu \mathrm{g}$. ethambutol $/ \mathrm{ml}$. was added.

The Sauton agar contained glycerol, $30 \mathrm{ml}$; sodium glutamate, $4.0 \mathrm{~g}$.; $\mathrm{KH}_{2} \mathrm{PO}_{4}, 0.5 \mathrm{~g}$.; $\mathrm{MgSO}_{4} \cdot 7 \mathrm{H}_{2} \mathrm{O}, 0.5 \mathrm{~g}$.; sodium citrate, $2 \cdot 0 \mathrm{~g}$.; ferric ammonium citrate, $0.05 \mathrm{~g}$.; purified agar, $30.0 \mathrm{~g}$; distilled water, $970 \mathrm{ml}$. The medium $\left(\mathrm{pH}^{\circ}{ }^{\circ}\right)$ was poured in $8 \mathrm{ml}$. quantities into tubes $\left(170 \times 17 \mathrm{~mm}\right.$.) and sterilized by autoclaving at $115^{\circ}$ for $30 \mathrm{~min}$., sloped and cooled. Slopes were surface inoculated with one loopful of the stock cultures and incubated at $37^{\circ}$ unless especially noted. Results were read after incubation for 2 weeks.

The Ziehl-Neelsen stain was carried out according to the method used by Gordon \& Smith (1953). In the present study, the term 'strong or complete' acid-fastness is used for organisms stained strongly red, and the term 'slight or weak' acid-fastness for organisms stained uniformly pinkish or feebly violet. Slight acid-fastness differs from 'partial' acidfastness as observed in nocardias. Partial acid-fastness indicates a state in which the 
majority of organisms are stained blue (non-acid-fast) and the minority stained red (acid-fast).

The diagnostic tests described by Cowan \& Steel (1965) were also used to distinguish between the genera.

Numerical analysis. The 'hypothetical mean organism' (HMO), a modification of the 'hypothetical median organism' of Liston, Wiebe \& Colwell (1963), is the term used to express a mean characterization of a species. HMOs were prepared by the method described previously (Tsukamura \& Mizuno, 1968; Tsukamura, 1969). The characters of a species were expressed by symbols $(+,-)$ and the S-value between two species was calculated as follows:

$$
\text { S-value }(\%)=\left(n_{\mathrm{s}} / n_{\mathrm{s}}+n_{\mathrm{d}}\right) \times 100 \%
$$

where $n_{\mathrm{s}}$ is the number of characters in which two HMO's showed similar code symbols $(++$ or --$)$ and $n_{\mathrm{d}}$ is the number of characters in which two HMO's showed different code symbols $(+-)$ (Tsukamura, I966, I969).

The characters used in the present study were identical to those used originally in a numerical taxonomic study of rapid- and slow-growing mycobacteria. In the present study, where rapid-growing mycobacteria and Nocardia strains were compared, 30 out of I00 proved to be ineffective, six showing negative matches and 24 showing positive matches.

Taxonomic distance was calculated according to the following equation (Lysenko \& Sneath, 1959):

$$
\text { Taxonomic distance }(d)=(100-x) / x \text {, }
$$

where $x$ is a mean $\mathrm{S}$-value $(\%)$ between the genera, and the dimension of a genus was expressed as the radius of a circle, $r=(\mathrm{I} 00-y) / y$, where $y$ is a mean S-value $(\%)$ within a genus.

Pathogenicity tests. Mice were inoculated intravenously by a challenge dose of $2 \mathrm{mg}$. moist weight, and guinea pigs, rabbits and chickens were inoculated intravenously with a challenge dose of $2 \mathrm{mg}$. moist weight or intramuscularily with a challenge dose of $10 \mathrm{mg}$. moist weight. Viable organisms were counted in the lungs, spleen, liver and kidneys three weeks after inoculation. This was done by taking a piece of the organ, adding an equal weight of $2 \%(\mathrm{w} / \mathrm{v}) \mathrm{NaOH}$ solution, homogenizing and then inoculating from the suspension to Ogawa egg medium. The pathogenicity test was not included among the characters used in the calculation of S-values.

\section{RESULTS AND DISCUSSION}

\section{General characters}

All the Ior isolates, 7I from sputa and 30 from soils, showed a similar morphology, typically short rods (and sometimes as coccoids), I $\mu \mathrm{m}$. by $\mathrm{I} \cdot 5$ to $2 \cdot 0 \mu \mathrm{m}$. Most strains were Gram-positive, though some of those isolated from sputa were Gram-variable or only weakly positive. The organisms showed slight acid-fastness staining uniformly light pink or light violet by the Ziehl-Neelsen method. The organisms were resistant to acid and alkali, being more resistant than nocardias and as resistant as mycobacteria (Table I).

Growth occurred after 2 to 3 days on egg media, Sauton agar and nutrient agar. The colonies growing on the first two media were pinkish or reddish (rarely orange) when incubated aerobically. The colonies remained light brownish or creamy if the air was limited (with paraffined cotton stopper or gum cap); grew at $28^{\circ}$ and $37^{\circ}$ but not at $45^{\circ}$; 
no mycelium or branching observed; no spores were formed; grew only under aerobic conditions. The organisms were catalase-positive, oxidase-negative and formed acid from glucose by oxidation.

\title{
Table I. Comparison of tolerance to sodium hydroxide and sulphuric acid among Mycobacterium, Gordona and Nocardia
}

\begin{abstract}
The organisms growing on Ogawa egg medium were harvested after incubation at $37^{\circ}$ for 7 days, homogenized by shaking with glass beads, suspended in distilled water (control), $1 \% \mathrm{NaOH}$ solution or $\mathrm{I} \% \mathrm{H}_{2} \mathrm{SO}_{4}$ solution to obtain a suspension of 2 to $5 \mathrm{mg}$. (moist weight) $/ \mathrm{ml}$., and allowed to stand at room temperature for $10 \mathrm{~min}$. The suspension was then immediately diluted with saline, and a series of tenfold dilutions was prepared. Samples of each dilution $(0.02 \mathrm{ml}$.) were inoculated onto Ogawa egg medium with a spiral loop and incubated at $37^{\circ}$ for 5 days (alkali or acid are neutralized in medium).
\end{abstract}

\begin{tabular}{|c|c|c|c|}
\hline \multirow[b]{2}{*}{ Strain } & \multicolumn{3}{|c|}{$\begin{array}{l}\text { Number of surviving organisms }(\%) \\
\text { after contact with: }\end{array}$} \\
\hline & Water & $1 \% \mathrm{NaOH}$ & $1 \% \mathrm{H}_{2} \mathrm{SO}_{4}$ \\
\hline 103 & $100 \cdot 0$ & 0.0219 & $9 \cdot 52$ \\
\hline 106 & $100 \cdot 0$ & 0.0860 & 17.0 \\
\hline atis SN 2 & $100 \cdot 0$ & 0.517 & 0.126 \\
\hline$m$ АТСС 19709 & $100 \cdot 0$ & $33 \cdot 2$ & $36 \cdot 0$ \\
\hline$m 334$ & $100 \cdot 0$ & $16 \cdot 6$ & 102.4 \\
\hline alis NCTC 10667 & $100 \cdot 0$ & $54 \cdot 2$ & 0.0189 \\
\hline alis TAKESHITA & $100 \cdot 0$ & $46 \cdot 3$ & 0.0810 \\
\hline NORIMATSU & $100 \cdot 0$ & 0.175 & $2 \cdot 10$ \\
\hline CTC 10668 & $100 \cdot 0$ & 0.214 & 0.536 \\
\hline es ATCC 23824 & $100 \cdot 0$ & $<0.0089$ & $<0.0089$ \\
\hline$a$ АTCC 23825 & $100 \cdot 0$ & $<0.0093$ & $<0.0093$ \\
\hline-1315 & $100 \cdot 0$ & 0.0462 & 0.0923 \\
\hline
\end{tabular}

\section{Taxonomic consideration}

In view of the above characters it was considered that the organisms occupy a taxonomic position near the genera Mycobacterium and Nocardia (Cowan \& Steel, I965). Thus a comparison was made between these organisms and representative strains of the taxa Mycobacterium (rapid-growing mycobacteria), 'Mycobacterium' rhodochrous and Nocardia. The comparison was carried out using eight characters previously found to be useful in differentiating between rapid-growing mycobacteria and nocardias (Tsukamura, 1970), the genus Mycobacterium having been divided into two subgenera, which approximately correspond to slow-growing and rapid-growing mycobacteria (Tsukamura, I967, 1970).

The organisms were differentiated from Nocardia by five of the eight characters (Table 2). They showed slight acid-fastness, lacked mycelium, formed acid from mannose, utilized sucrose as a sole carbon source, and reduced nitrate to nitrite. Alternatively, the organisms differed from Mycobacterium in four characters; they were not strongly acid-fast and showed no arylsulphatase activity at 2 weeks, they utilized sucrose as a sole carbon source, but were unable to grow on trimethylene diamine as a simultaneous carbon and nitrogen source (Table 2).

The organisms most resembled 'Mycobacterium' rhodochrous, the taxonomic position of which is not yet established. They could be differentiated from the ' $M$.' rhodochrous strains by only one of the eight distinguishing characters (Table 2). The organisms formed acid from mannose, showing growth in a medium containing mannose as the sole source of carbon, while the ' $M$.' rhodochrous strains did not form acid from mannose, although growth occurred in the presence of mannose.

Gordon \& Mihm (1957, 1962) stated that most strains of Nocardia asteroides, N. brasi- 
iensis and $N$. caviae produced acid from mannose but Tsukamura (1969, 1970) reported that nocardias did not form acid from mannose. This disagreement is probably due to Gordon \& Mihm observing acid production after 28 days at $28^{\circ}$ (Gordon \& Smith, I953), whereas Tsukamura recorded acid production after incubation at $28^{\circ}$ for I 4 days (Tsukamura, 1967). In addition, the media used are also different.

\section{Table 2. Comparison between strains of Nocardia, Gordona, 'Mycobacterium' rhodochrous and Mycobacterium (rapid-growing mycobacteria)}

Symbols $(+$ or -$)$ are expressed by a feature shown by more than $51 \%$ of species, the characters of a species being expressed as a HMO. Only the characters of 'Mycobacterium' rhodochrous are expressed by the HMO itself.

\section{Character*}

(1) Strong acid-fastness

(2) Slight acid-fastness

(3) Fragmenting mycelium

(4) Nitrate reduction

(5) Arylsulphatase (2 weeks)

(6) Acid from mannose

(7) Sucrose as C source

(8) Trimethylene diamine as simultaneous $\mathrm{N}$ and $\mathrm{C}$ sources

\section{Nocardia}

-
-
+
-
-
-
-
-

'Mycobacterium'

\section{Gordona} rhodochrous

$\begin{array}{ll}- & + \\ + & + \\ - & - \\ + & + \\ - & + \\ + & + \\ - & +\end{array}$

* Except for the utilization of sucrose as sole $\mathbf{C}$ source and the slight acid-fastness, the characters shown here are the distinguishing characters previously described for Mycobacterium and Nocardia (Tsukamura, 1970).

The organisms were differentiated from Mycococcus luteus, BKM-B-963, by many characters: (I) the organisms were slightly acid-fast, while Mycococcus is not acid-fast; (2) the organisms occurred as rods, while Mycococcus occurs as coccoids; (3) the organisms reduced nitrate to nitrite, while $M y$ cococcus does not; (4) the organisms grew well on egg media containing malachite green (for example, Ogawa egg medium), while Mycococcus does not grow on such media; (5) the organisms showed rough, reddish or pinkish colonies on Sauton agar, while Mycococcus shows smooth, yellowish colonies; (6) the organisms utilized glutamate as a simultaneous nitrogen and carbon source, while Mycococcus does not utilize it; (7) the organisms utilized serine, methionine, acetamide, urea, pyrazinamide, etc. as sole nitrogen sources, while Mycococcus does not utilize them.

The strain BKM B-963 of Mycococcus luteus seems to be the only strain of the genus Mycococcus obtainable at present (personal communication of Dr M. Fateeva, All Union Collection of Micro-organisms, Moscow, U.S.S.R.). Two strains of the genus Mycococcus in the American Type Culture Collection are not Mycococcus but seem to belong either to the genus Corynebacterium or to Arthrobacter (personal communication from Dr M. Isono, Fermentation Research Institute, Osaka, Japan, who deposited these strains). According to Bergey's Manual (I957) the genus Mycococcus generally consists of coccoids variable in size and shape and is not acid-fast. Our organisms are rods and slightly acid-fast.

It would appear from these results that the organisms cannot be placed in any of the established genera. It was therefore considered appropriate to create a new genus for these organisms.

The generic name Gordona has been chosen for these organisms, taking the latinized name of Dr Ruth E. Gordon, who studied extensively 'Mycobacterium' rhodochrous (included later as a member of Gordona). 
The nomenclature of 'Mycobacterium' rhodochrous

An organism named Micrococcus rhodochrous (Zopf) Migula (I900) was moved by Gordon \& Mihm (1957, 1959) into the genus Mycobacterium as Mycobacterium rhodochrous. The taxonomic position of this taxon was later questioned by Gordon herself. She stated that this organism showed characters intermediate between Mycobacterium and Nocardia but differed from Corynebacterium. The confused taxonomic position of this organism is expressed by the title of her paper: 'Some strains in search of a genus-Corynebacterium, Mycobacterium, Nocardia or what?' (Gordon, 1966). Following this paper, the name 'Mycobacterium' rhodochrous has been widely used. The first problem is to decide whether or not our isolates belong to the same genus as 'Mycobacterium' rhodochrous. A comparison was therefore carried out using the organisms isolated by us and several 'Mycobacterium' rhodochrous strains. The results are shown in Table 3.

\section{Table 3. Comparison between Gordona strains and 'Mycobacterium' rhodochrous strains}

\section{Character*}

Strong acid-fastness

Weak acid-fastness

Mycelium

Nitrate reduction

Arylsulphatase (2 weeks)

Acid from mannose

Sucrose, sole carbon source

Trimethylene diamine, nitrogen and carbon sources

Acid from glucose

Tolerance to $0.2 \%$ picric acid

Utilization as sole carbon source: acetate succinate malate pyruvate fumarate

$\begin{array}{ccccccc}\text { Gordona } & \text { “Mycobacterium rhodochrous } \\ \text { strainst } & \text { I } & 2 & 3 & 4 & 5 & 6 \\ - & - & - & - & - & - & - \\ + & + & - & + & + & + & + \\ - & - & - & - & - & - & - \\ + & + & + & - & + & + & - \\ - & - & - & - & - & - & - \\ + & -\S & + & + & -\S & -\S & - \\ + & + & + & + & - & + & + \\ - & - & - & - & - & - & - \\ & & & & & & \\ + & + & + & + & + & + & + \\ + & + & + & + & + & + & + \\ & & & & & & \\ + & + & + & + & + & + & + \\ + & + & + & + & + & + & + \\ + & + & + & + & + & + & + \\ + & + & + & + & + & + & + \\ + & + & + & + & + & + & +\end{array}$

* Characters shown in upper part are distinguishing ones for Mycobacterium (rapid-growing mycobacteria) and Nocardia. Characters shown in lower part are distinguishing ones for slow-growing and rapid-growing mycobacteria.

$\uparrow$ All of the IoI strains of Gordona tested showed similar results.

$\mp \mathrm{I}$, ATCC $13808 ; 2$, tsu; $3, \mathrm{~N} 30 ; 4, \mathrm{~N} 31 ; 5, \mathrm{~N} 55 ; 6, \mathrm{~N} 56$. Strains, tsu and N 30 were tested at $28^{\circ}$ as these two could not grow at $37^{\circ}$.

$\S$ Acid not formed from mannose but growth occurs in presence of mannose.

All of the IOI isolates showed the same distinguishing characters. On the other hand, 'Mycobacterium' rhodochrous strains differed by only one or two characters from the organisms isolated from sputum and soil. The 'Mycobacterium' rhodochrous strains were also found to be similar to our isolates by means of the characters shown in the diagnostic table (p. 55) of Cowan \& Steel (I965). These results suggested that our isolates and the ' $M$.' rhodochrous strains belonged to the same genus. 
Table 4. Frequency of positive characters in each species of Gordona

Character

G. bronchialis

No. of strains tested

I. Gram reaction

2. Strong acid-fastness

3. Slight acid-fastness

4. Permanent mycelium

5. Temporary or fragmenting mycelium

6. Rod shape

7. Compact grouping (like cord)

8. Rough colonial morphology

9. Colony pigmentation

10. Photochromogenicity

II. Rapid growth

12. Catalase

13. Nitrate reduction

14. Arylsulphatase (3 days)

15. Arylsulphatase (2 weeks)

16. Salicylate degradation

17. PAS degradation

18. Growth on $0.2 \%$ sodium $p$-aminosalicylate

19. Growth on $62.5 \mu \mathrm{g}$. $\mathrm{NH}_{2} \mathrm{OH} . \mathrm{HCl} / \mathrm{ml}$.

20. Growth on $125 \mu \mathrm{g}$. $\mathrm{NH}_{2} \mathrm{OH} . \mathrm{HCl} / \mathrm{ml}$.

2I. Growth on $256 \mu \mathrm{g}$. $\mathrm{NH}_{2} \mathrm{OH} . \mathrm{HCl} / \mathrm{ml}$.

22. Growth on $500 \mu \mathrm{g}$. $\mathrm{NH}_{2} \mathrm{OH} . \mathrm{HCl} / \mathrm{ml}$.

23. Tolerance to $0.1 \%$ picric acid

24. Tolerance to $0.2 \%$ picric acid

25. Growth at $28^{\circ}$

26. Growth at $37^{\circ}$

27. Growth at $45^{\circ}$

28. Growth at $52^{\circ}$

29. Acetamidase

30. Benzamidase

3I. Urease

32. Isonicotinamidase

33. Nicotinamidase

34. Pyrazinamidase

35. Salicylamidase

36. Allantoinase

37. Succinamidase

38. Malonamidase

39. Acetate (as $\mathrm{C}$ source)

40. Citrate (as C source)

41. Succinate (as C source)

42. Malate (as $\mathrm{C}$ source)

43. Pyruvate (as $C$ source)

44. Benzoate (as $\mathrm{C}$ source)

45. Malonate (as $\mathrm{C}$ source)

46. Fumarate (as $\mathrm{C}$ source)

47. Acid from glucose

48. Acid from mannose

49. Acid from galactose

50. Acid from arabinose

5I. Acid from xylose

52. Acid from rhamnose

53. Acid from trehalose

54. Acid from raffinose

55. Acid from inositol

56. Acid from mannitol

57. Acid from sorbitol

\begin{tabular}{|c|c|c|}
\hline $4 I$ & 10 & 20 \\
\hline $4 I$ & 10 & 20 \\
\hline 0 & 0 & 0 \\
\hline 4I & 10 & 20 \\
\hline 0 & 0 & 0 \\
\hline 0 & 0 & 0 \\
\hline $4 I$ & 10 & 20 \\
\hline 34 & 3 & 4 \\
\hline $4 I$ & $10^{*}$ & $20^{*}$ \\
\hline $4 I$ & 10 & 20 \\
\hline 0 & 0 & 0 \\
\hline $4 I$ & 10 & 20 \\
\hline $4 \mathrm{I}$ & 10 & 20 \\
\hline 40 & 8 & 19 \\
\hline 0 & 0 & 0 \\
\hline 0 & 0 & 0 \\
\hline 0 & 0 & 0 \\
\hline 0 & 0 & 0 \\
\hline $4 I$ & 10 & 20 \\
\hline 4I & 10 & 20 \\
\hline 38 & IO & 20 \\
\hline 5 & 9 & I6 \\
\hline 0 & 0 & 0 \\
\hline $4 I$ & 10 & 20 \\
\hline $4 I$ & 10 & 20 \\
\hline $4 I$ & 10 & 20 \\
\hline $4 I$ & 10 & 20 \\
\hline 0 & 0 & 0 \\
\hline 0 & 0 & 0 \\
\hline 40 & 0 & 0 \\
\hline 0 & 0 & 0 \\
\hline $4 \mathrm{I}$ & 10 & 20 \\
\hline 0 & 0 & o \\
\hline 35 & 0 & I 6 \\
\hline 34 & 0 & 16 \\
\hline 0 & 0 & 0 \\
\hline 0 & 10 & 19 \\
\hline 0 & 0 & 0 \\
\hline 0 & 0 & 0 \\
\hline $4 \mathrm{I}$ & 10 & 20 \\
\hline I 2 & 10 & I 3 \\
\hline $4 \mathrm{I}$ & 9 & 20 \\
\hline $4 \mathrm{I}$ & 9 & 20 \\
\hline $4 \mathrm{I}$ & 10 & 20 \\
\hline I 3 & 10 & I \\
\hline 0 & 0 & 0 \\
\hline $4 \mathrm{I}$ & 9 & 20 \\
\hline $4 \mathrm{I}$ & 10 & 20 \\
\hline $4 I$ & 10 & 20 \\
\hline 0 & 0 & 0 \\
\hline 0 & 0 & 0 \\
\hline 0 & 0 & 0 \\
\hline 0 & 0 & 20 \\
\hline 40 & 7 & 20 \\
\hline 0 & 0 & 0 \\
\hline 40 & 0 & 0 \\
\hline IO & 10 & 20 \\
\hline 0 & 10 & 20 \\
\hline
\end{tabular}

* Intermediate between S- and R-types. 
Table 4 (cont.)

\title{
Character
}

G.bronchialis

G. rubra

G. terrae

\author{
58. Glycerol (as C source) \\ 59. Glucose (as $\mathrm{C}$ source) \\ 6o. Mannose (as $\mathrm{C}$ source) \\ 6I. Galactose (as C source) \\ 62. Arabinose (as $\mathrm{C}$ source) \\ 63. Xylose (as C source) \\ 64. Rhamnose (as $C$ source) \\ 65. Trehalose (as C source) \\ 66. Raffinose (as $\mathrm{C}$ source) \\ 67. Inositol (as $\mathrm{C}$ source) \\ 68. Mannitol (as C source) \\ 69. Sorbitol (as C source) \\ 70. Fructose (as C source) \\ 7I. Sucrose (as C source) \\ 72. Ethanol (as C source) \\ 73. Propanol (as $\mathrm{C}$ source) \\ 74. Propylene glycol (as C source) \\ 75. I,3-Butylene glycol (as $\mathrm{C}$ source) \\ 76. I,4-Butylene glycol (as $\mathrm{C}$ source) \\ 77. 2,3-Butylene glycol (as $\mathrm{C}$ source) \\ 78. L-Glutamate (as N-C sources) \\ 79. L-Serine (as $\mathrm{N}-\mathrm{C}$ sources) \\ 80. Glucosamine $\mathrm{HCl}$ (as $\mathrm{N}-\mathrm{C}$ sources) \\ 8I. Acetamide (as N-C sources) \\ 82. Benzamide (as $\mathrm{N}-\mathrm{C}$ sources) \\ 83. Monoethanolamine (as $\mathrm{N}-\mathrm{C}$ sources) \\ 84. Trimethylene diamine (as $\mathrm{N}-\mathrm{C}$ sources) \\ 85. L-Glutamate (as $\mathrm{N}$ source) \\ 86. L-Serine (as $\mathrm{N}$ source) \\ 87. L-Methionine (as $\mathrm{N}$ source) \\ 88. Acetamide (as $\mathrm{N}$ source) \\ 89. Benzamide (as $\mathrm{N}$ source) \\ 9o. Urea (as $\mathrm{N}$ source) \\ 9I. Pyrazinamide (as N source) \\ 92. Isonicotinamide (as $\mathrm{N}$ source) \\ 93. Nicotinamide (as $\mathbf{N}$ source) \\ 94. Succinamide (as $\mathrm{N}$ source) \\ 95. Nitrate (as $\mathrm{N}$ source) \\ 96. Nitrite (as $\mathrm{N}$ source) \\ 97. Nicotinic acid production \\ 98. Growth on TCH medium ( $10 \mu \mathrm{g} . / \mathrm{ml}$ ) \\ 99. Growth on salicylate medium $(0.05 \%)$ \\ IOO. Growth on salicylate medium (0.I\%)
}

No. of strains tested $\ldots \quad 4 \mathrm{I}$

$4 \mathrm{I}$
$4 \mathrm{I}$
$4 \mathrm{I}$
$4 \mathrm{I}$
0
0
0
0
$4 \mathrm{I}$
0
40
12
5
$4 \mathrm{I}$
$4 \mathrm{I}$
$4 \mathrm{I}$
$4 \mathrm{I}$
40
8
6
$\mathrm{II}$
$4 \mathrm{I}$
3
$\mathrm{I}$
40
0
0
0
$4 \mathrm{I}$
40
39
$4 \mathrm{I}$
$\mathrm{I}$
$4 \mathrm{I}$
$4 \mathrm{I}$
30
38
$3 \mathrm{I}$
25
0
0
$4 \mathrm{I}$
38

\begin{tabular}{|c|c|}
\hline IO & 20 \\
\hline IO & 20 \\
\hline 10 & 20 \\
\hline IO & 20 \\
\hline 0 & 0 \\
\hline 0 & 0 \\
\hline 0 & 0 \\
\hline 0 & 20 \\
\hline 10 & 20 \\
\hline 0 & 0 \\
\hline 0 & o \\
\hline 10 & 20 \\
\hline IO & 20 \\
\hline ro & 20 \\
\hline IO & 20 \\
\hline Io & 20 \\
\hline IO & 20 \\
\hline 0 & 0 \\
\hline o & 0 \\
\hline 8 & 0 \\
\hline IO & I \\
\hline 10 & 20 \\
\hline 0 & 0 \\
\hline 10 & 18 \\
\hline 0 & 0 \\
\hline 0 & 0 \\
\hline 10 & 19 \\
\hline 0 & 0 \\
\hline Io & 20 \\
\hline IO & 20 \\
\hline 7 & 19 \\
\hline 6 & 19 \\
\hline 5 & 18 \\
\hline 0 & 20 \\
\hline 6 & 20 \\
\hline 7 & 20 \\
\hline 3 & 20 \\
\hline 10 & 20 \\
\hline IO & 20 \\
\hline 0 & 0 \\
\hline 0 & 0 \\
\hline Io & 20 \\
\hline IO & 20 \\
\hline IO & I 8 \\
\hline
\end{tabular}

\section{Species of the genus Gordona}

The strains belonging to the genus Gordona were examined for the I00 characters shown in Table 4. Of the IoI strains isolated from sputum and soil, 7I were classified into three species. The 4I strains from sputum formed one species, which was called Gordona bronchialis. Thirty strains isolated from the soil constituted the remaining two species, Gordona rubra and G. terrae.

Among the remaining 30 strains, which were isolated from sputum and did not belong to Gordona bronchialis, 14 seemed to be a variety of the species G. bronchialis, but this was not certain. Four strains seemed to form a possible fourth species, but this is not presented in the present paper. The other strains seemed to belong to miscellaneous species 
but specific names were not proposed, as such species would have included only one or two strains. Strains received as 'Mycobacterium' rhodochrous seemed to belong to these miscellanous species.

The frequency of occurrence of positive characters in the three named species are shown in Table 4. The characters which are not shown in Table 4 are as follows: (I) tolerant to $5 \mu \mathrm{g}$. ethambutol $/ \mathrm{ml}$.; (2) tolerant to $0 . \mathrm{I} \% \mathrm{NaNO}_{2}$; (3) tolerant to $0.2 \% \mathrm{NaNO}_{2}$; (4) tolerant to $\mathrm{I} \%$ Tween 80 . The type strains and two other strains of each species were tested for their pathogenicity in mice, guinea pigs, rabbits and chickens. All of the strains tested failed to produce any visible lesions in lungs, spleen, liver and kidneys, and no viable organism was found in the organs.

Table 5. Mean $S$-values and their standard deviations to the hypothetical mean organism (HMO) of itself and to the HMO of other species

The value in table shows [(mean S-value) \pm (standard deviation)], and the number in parentheses the number of test strains.

\begin{tabular}{lccc} 
& \multicolumn{3}{c}{ Mean S-value $(\%)$ to the HMO of } \\
Species & G. bronchialis & G. rubra & G. terrae \\
G. bronchialis & $94 \cdot 76 \pm 2 \cdot 52^{*}$ & $79 \cdot 59 \pm 2 \cdot 58$ & $8 \mathrm{r} \cdot 68 \pm 2 \cdot 70$ \\
& $(n=4 \mathrm{I})$ & $(n=4 \mathrm{I})$ & $(n=4 \mathrm{I})$ \\
G. rubra & $75 \cdot 60 \pm 2 \cdot 36$ & $93 \cdot 40 \pm \mathrm{I} \cdot 26^{*}$ & $86 \cdot 46 \pm 2 \cdot 80$ \\
& $(n=10)$ & $(n=10)$ & $(n=\mathrm{I}))$ \\
G. terrae & $83 \cdot 00 \pm \mathrm{I} \cdot 78$ & $88 \cdot 35 \pm \mathrm{I} \cdot 39$ & $97 \cdot 30 \pm \mathrm{I} \cdot 8 \mathrm{I} *$ \\
& $(n=20)$ & $(n=20)$ & $(n=20)$ \\
& $*$ Intraspecies mean S-value. &
\end{tabular}

Organisms of the genus Gordona can be found in the sputum of patients with cavitary pulmonary tuberculosis and bronchiectasis and are resistant to alkali. Though growing rapidly on successive subcultures, the organisms grow only slowly on primary isolation. Moreover, the colonies of the organisms look like tubercle bacilli when cultivated in containers with a gum cap or paraffined cotton stopper. It is possible, therefore, that the Gordona organisms are sometimes mistaken for tubercle bacilli. In a co-operative study undertaken by 13 Japanese national sanatoria, 57 strains $(0.34 \%)$ of Gordona organisms were found amongst 16,795 strains which grew after treatment with alkali. These 57 strains of the Gordona organisms were sent to our laboratory as 'atypical' acid-fast organisms.

To confirm that the three species were well differentiated, the following calculation was made. Intraspecies mean S-values (a mean S-value for the membership of a species to the HMO of itself) and interspecies mean S-values (a mean S-value for the membership of a species to the HMO of another species) are shown in Table 5. The difference between intra- and inter-mean S-values was greater than the addition of both standard deviations in any combination of two species. This finding indicated that these species were clearly separable from each other (with a statistically significant difference, $p=0.00 \mathrm{I}$, by ' $t$ ' test).

Gordona bronchialis is proposed as the type species. The following type strains are deposited in the National Collection of Type Cultures, London, and the American Type Culture Collection, Rockville, Maryland, U.S.A.: Gordona bronchialis strain 34I0; NCTC 10667; ATCC 25592; Gordona rubra strain 3605; NCTC 10668; ATCC 25593; Gordona terrae strain 3612; NCTC 10669; ATCC 25594. 
Species-distinguishing characters

Distinguishing characters for the species of the genus Gordona are shown in Table 6. These characters were previously found useful for the differentiation of rapid-growing mycobacteria (Gordon \& Mihm, I959; Bönicke, I962; Tsukamura, I966, 1967; Tsukamura, Mizuno \& Tsukamura, 1968) and nocardias (Tsukamura, I969).

\section{Table 6. Distinguishing characters for differentiation of the species of the genus Gordona}

\begin{tabular}{|c|c|c|c|}
\hline Character & G.bronchialis & G. rubra & G. terrae \\
\hline Number of strains tested $\ldots$ & $4 \mathrm{I}$ & Io & 20 \\
\hline Acetamidase & + & - & - \\
\hline Urease & + & + & + \\
\hline Nicotinamidase & + & - & + \\
\hline Pyrazinamidase & + & - & + \\
\hline Allantoinase & - & + & + \\
\hline L-Glutamate as $\mathrm{N}$ and $\mathrm{C}$ sources* & + & + & + \\
\hline L-Serine as $\mathrm{N}$ and $\mathrm{C}$ sources* & - & - & - \\
\hline Glucosamine as $\mathrm{N}$ and $\mathrm{C}$ sources* & $\mp$ & + & + \\
\hline Acetamide as $\mathrm{N}$ and $\mathrm{C}$ sources* & + & - & - \\
\hline Benzamide as $\mathrm{N}$ and $\mathrm{C}$ sources* & - & - & - \\
\hline Monoethanolamine as $\mathrm{N}$ and $\mathrm{C}$ sources* & - & + & + \\
\hline Trimethylene diamine as $\mathrm{N}$ and $\mathrm{C}$ sources* & - & - & - \\
\hline Citrate as sole $\mathrm{C}$ source & $\mp$ & + & + \\
\hline Benzoate as sole $C$ source & $\mp$ & + & - \\
\hline Propylene glycol as sole $\mathrm{C}$ source & + & - & - \\
\hline Acid from rhamnose & - & - & + \\
\hline Acid from inositol & + & - & - \\
\hline Acid from mannitol & $\mp$ & + & + \\
\hline Acid from sorbitol & - & + & + \\
\hline
\end{tabular}

$+=$ Positive in more than $81 \% ; \pm=$ positive in 51 to $80 \% ; \mp=$ positive in 21 to $50 \% ;-=$ positive in less than $20 \%$.

* Utilization for growth as simultaneous nitrogen and carbon sources (Tsukamura, 1966, 1967).

Relationship between Mycobacterium, Gordona and Nocardia observed by numerical analysis

Comparing HMO's, a S-value was prepared for the species of Mycobacterium (rapidgrowing mycobacteria), Gordona and Nocardia, and used to calculate the taxonomic distance between the genera (Table 7 and Fig. 1 ).

The taxonomic distance between Mycobacterium and Gordona $(0.387)$ is greater than that taxonomic distance between Gordona and Nocardia $(0 \cdot 255)$. This finding shows that the genera Gordona and Nocardia have a higher phenetic similarity than the genera Gordona and Mycobacterium, and suggests that the genus Gordona should be included in the family Actinomycetaceae to which the genus Nocardia belongs.

The greatest difficulty we met in the present study was that the similarity coefficient between the species of the same genus was occasionally less than that between the species of different genera (Table 7). According to the current concept of genera, the species of a genus should have shown a higher S-value than the species of different genera. At present, an acceptable answer to this difficulty remains to be found. The odd result shown in Table 7 might have been caused by overlap between genera (Fig. I) or by uneven selection of characters (though the characters used were selected without bias) in which case the numerical taxonomy would require more characters than are considered as sufficient at present. 
Since a species named Nocardia rubra by the present author (Tsukamura, 1969) contained several strains named 'Mycobacterium' rhodochrous by Gordon \& Mihm (I957), the author would like to make some comment on the relationship between the genus Gordona and the species $N$. rubra. On the basis of the distinguishing characters shown in Table 2, N. rubra differs from the genus Gordona as follows: (1) N. rubra does not show slight

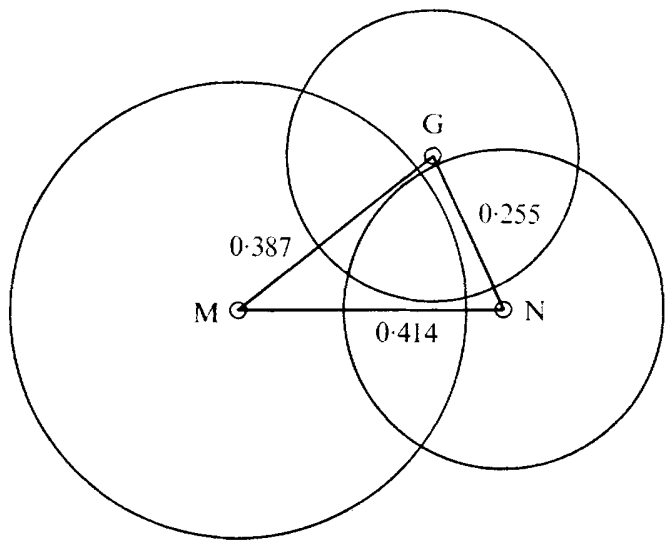

Fig. I. Taxonomic relationship among Mycobacterium (M) (rapid-growing mycobacteria), Gordona (G) and Nocardia $(\mathrm{N})$. Taxonomic distance between the genera was expressed as $d=(100-x) / x$, where $x$ is a mean $\mathrm{S}$-value $(\%)$ between the genera. Extent of a genus was expressed as the radius of a circle, $r=(100-y) / y$, where $y$ is a mean $\mathrm{S}$-value $(\%)$ within a genus. Taxonomic distances are written in figures. Values of $r$ are as follows: $r_{M}=0.35 \mathrm{I} ; r_{G}=0.220 ; r_{\mathrm{N}}=0.244$.

Table 7. S-value table composed of $S$-values between the HMOs of species of Mycobacterium (rapid-growing mycobacteria), Gordona and Nocardia

$\begin{array}{lrrrrrrrrrrrrrrr} & \text { I } & 2 & 3 & 4 & 5 & 6 & 7 & 8 & 9 & \text { I0 } & \text { I I } & \text { I2 } & \text { I3 } & \text { I4 } \\ \text { I. Mycobacterium abscessus } & 100 & - & - & - & - & - & - & - & - & - & - & - & - & - \\ \text { 2. M. fortuitum } & 85 & 100 & - & - & - & - & - & - & - & - & - & - & - & - \\ \text { 3. M. phlei } & 73 & 76 & 100 & - & - & - & - & - & - & - & - & - & - & - \\ \text { 4. M. aurum } & 71 & 83 & 77 & 100 & - & - & - & - & - & - & - & - & - & - \\ \text { 5. M. smegmatis } & 58 & 67 & 76 & 74 & 100 & - & - & - & - & - & - & - & - & - \\ \text { 6. Gordona rubra } & 69 & 76 & 7 \mathrm{I} & 73 & 64 & 100 & - & - & - & - & - & - & - & - \\ \text { 7. G. terrae } & 70 & 73 & 76 & 74 & 73 & 87 & 100 & - & - & - & - & - & - & - \\ \text { 8. G. bronchialis } & 75 & 76 & 77 & 79 & 68 & 78 & 85 & 100 & - & - & - & - & - & - \\ \text { 9. 'M.' rhodochrous* } & 74 & 73 & 76 & 70 & 55 & 79 & 80 & 83 & 100 & - & - & - & - & - \\ \text { 10. Nocardia asteroides } & 77 & 72 & 77 & 67 & 56 & 78 & 81 & 84 & 87 & 100 & - & - & - & - \\ \text { I. } \text { N. brasiliensis } & 73 & 68 & 71 & 67 & 62 & 76 & 77 & 80 & 81 & 88 & 100 & - & - & - \\ \text { I2. N. caviae } & 75 & 72 & 77 & 73 & 64 & 76 & 79 & 78 & 79 & 84 & 84 & 100 & - & - \\ \text { I3. N. farcinica } & 69 & 74 & 71 & 75 & 64 & 70 & 77 & 78 & 79 & 80 & 74 & 78 & \text { I00 } & - \\ \text { I4. N. rubra } & 72 & 79 & 74 & 76 & 63 & 85 & 86 & 81 & 82 & 81 & 79 & 77 & 79 & \text { I00 }\end{array}$

* This is not a HMO but a feature of characters of strain ATCC 13808 of 'Mycobacterium' rhodochrous.

acid-fastness but shows partial acid-fastness; (2) N. rubra shows fragmenting mycelium; (3) N. rubra shows negative nitrate reduction. Like the Gordona species and unlike the other species of the genus Nocardia, N. rubra usually utilizes sucrose as a sole carbon source and forms acid from mannose (Tsukamura, I969). Furthermore, among the Nocardia species, $N$. rubra shows the highest S-values to the HMOs of the Gordona species (Table 7). In view of these findings, N. rubra is regarded as an intermediate between the 
genera Gordona and Nocardia. Nocardia rubra has been differentiated from the genus Gordona by the distinguishing characters and there is no decisive reason for eliminating it from the genus Nocardia.

The author thanks Dr M. Goodfellow, Department of Microbiology, Medical School, University of Newcastle upon Tyne, and Dr M. Fateeva, All Union Collection of Microorganisms, Moscow, U.S.S.R., for the 'Mycobacterium' rhodochrous strains and the Mycococcus luteus strain, respectively.

\section{REFERENCES}

Bergey's Manual of Determinative Bacteriology (1957). $7^{\text {th }}$ edn. Edited by R. S. Breed, E. G. D. Murray \& N. R. Smith. Baltimore: Williams \& Wilkins.

BöNICKE, R. (1962). L'identification des mycobactéries à l'aide de méthodes bioquimiques. Bulletin de l'Union Internationale contre la Tuberculose 32, 13-76.

Cowan, S. T. \& STeEL, K. J. (1965). Manual for the Identification of Medical Bacteria. Cambridge University Press.

Gordon, R. E. (1966). Some strains in search of a genus-Corynebacterium, Mycobacterium, Nocardia or what? Journal of General Microbiology 43, 329-343.

Gordon, R. E. \& MiнM, J. M. (I957). A comparative study of some strains received as nocardiase. Journal of Bacteriology 73, 15-27.

Gordon, R. E. \& Mirm, J. M. (1959). A comparison of four species of mycobacteria. Journal of General Microbiology 2r, 736-748.

GoRdon, R. E. \& Mrнm, J. M. (1962). Identification of Nocardia caviae (Erikson) nov. comb. Annals of the New York Academy of Sciences 98, 628-636.

Gordon, R. E. \& SMIrH, M. M. (1953). Rapidly growing, acid fast bacteria. I. Species' descriptions of Mycobacterium phlei Lehmann and Neumann and Mycobacterium smegmatis (Trevisan) Lehmann and Neumann. Journal of Bacteriology 66, $4 \mathrm{I}-48$.

Liston, J., Wiebe, W. \& Colwell, R. R. (1963). Quantitative approach to the study of bacterial species. Journal of Bacteriology 85, $106 \mathrm{I}-1070$.

Lysenko, O. \& SNEATH, P. H. A. (1959). The use of models in bacterial classification. Journal of General Microbiology 20, 284-290.

Migula, W. (1900). System der Bakterien. Jena: Gustav Fischer. (Cited from Bergey's Manual (1957)).

Tsuramura, M. (1962). Differentiation of Mycobacterium tuberculosis from other mycobacteria by sodium salicylate susceptibility. American Review of Respiratory Diseases 86, 8I-83.

Tsukamura, M. (1966). Adansonian classification of mycobacteria. Journal of General Microbiology 45, 253-273.

TsuKamura, M. (1967). Identification of mycobacteria. Tubercle, London 48, 3I I-338.

Tsukamura, M. (1969). Numerical taxonomy of the genus Nocardia. Journal of General Microbiology 56, $265-287$.

TsuKAmURA, M. (1970). Relationship between Mycobacterium and Nocardia. Japanese Journal of Microbiology I4, $187-195$.

Tsuramura, M. \& Mizuno, S. (1968). 'Hypothetical mean organisms' of mycobacteria. A study of classification of mycobacteria. Japanese Journal of Microbiology 12, 371-384.

Tsukamura, M., Mizuno, S. \& Tsukamura, S. (1968). Classification of rapidly growing mycobacteria. Japanese Journal of Microbiology 12, 15I-166. 